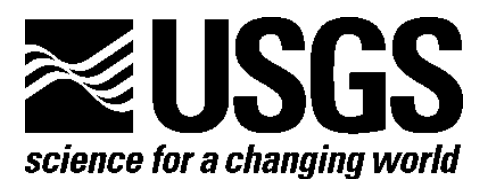

\title{
Deposit Model for Volcanogenic Uranium Deposits
}

By George N. Breit and Susan M. Hall

Open-File Report 2011-1255

U.S. Department of the Interior

U.S. Geological Survey 


\section{U.S. Department of the Interior \\ KEN SALAZAR, Secretary}

\section{U.S. Geological Survey \\ Marcia K. McNutt, Director}

U.S. Geological Survey, Reston, Virginia: 2011

For product and ordering information:

World Wide Web: http://www.usgs.gov/pubprod

Telephone: 1-888-ASK-USGS

For more information on the USGS—-the Federal source for science about the Earth,

its natural and living resources, natural hazards, and the environment:

World Wide Web: http://www.usgs.gov

Telephone: 1-888-ASK-USGS

Suggested citation:

Breit, G.N., and Hall, S.M., 2011, Deposit model for volcanogenic uranium deposits: U.S. Geological Survey Open-File Report 2011-1255, 5 p.

Any use of trade, product, or firm names is for descriptive purposes only and does not imply endorsement by the U.S. Government.

Although this report is in the public domain, permission must be secured from the individual copyright owners to reproduce any copyrighted material contained within this report. 


\section{Contents}

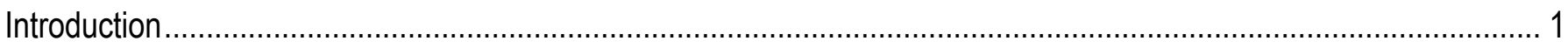

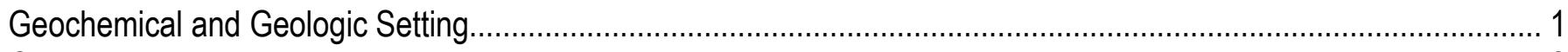

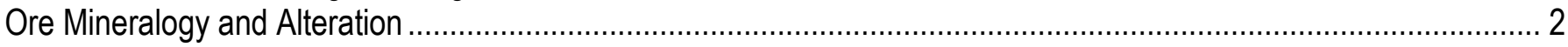

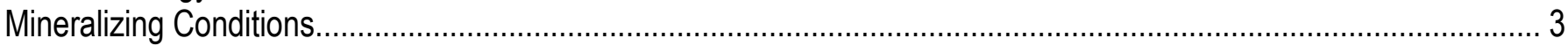

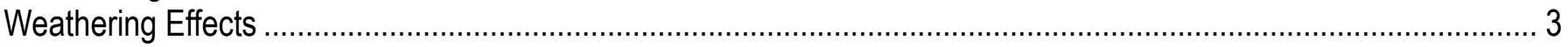

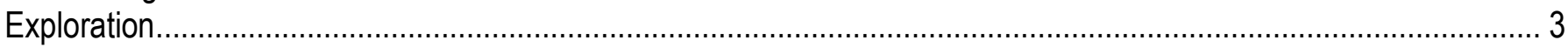

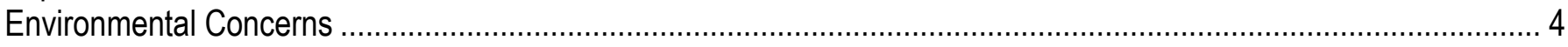

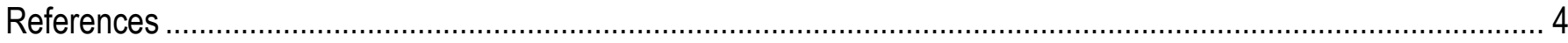




\title{
Deposit Model for Volcanogenic Uranium Deposits
}

\author{
By George N. Breit and Susan M. Hall
}

\section{Introduction}

Volcanism is a major contributor to the formation of important uranium deposits both close to centers of eruption and more distal as a result of deposition of ash with leachable uranium (Nash, 2010). Hydrothermal fluids that are driven by magmatic heat proximal to some volcanic centers directly form some deposits. These fluids leach uranium from U-bearing silicic volcanic rocks and concentrate it at sites of deposition within veins, stockworks, breccias, volcaniclastic rocks, and lacustrine caldera sediments (Goodell, 1985). The volcanogenic uranium deposit model presented here summarizes attributes of those deposits and follows the focus of the International Atomic Energy Agency (IAEA) caldera-hosted uranium deposit model. Although inferred by some to have a volcanic component to their origin, iron oxide-copper-gold (IOCG) deposits with economically recoverable uranium contents are not considered in this model.

The IAEA's tabulation of volcanogenic uranium deposits lists 100 deposits in 20 countries, with major deposits in Russia, Mongolia, and China. Collectively these deposits are estimated to contain uranium resources of approximately 500,000 tons $(\mathrm{t})$ of uranium $(\mathrm{U})$, which amounts to 6 percent of the known global resources (IAEA, 2009). Prior to the 1990s, these deposits were considered to be small (less than $10,000 \mathrm{t} \mathrm{U}$ ) with relatively low to moderate grades [0.05 to 0.2 weight percent (wt.\%) U]. Recent availability of information on volcanogenic uranium deposits in Asia highlighted the large resource potential of this deposit type. For example, the Streltsovskoye district in eastern Russia produced more than 100,000 $\mathrm{t} \mathrm{U}$ as of 2005; with equivalent resources remaining (IAEA, 2009; Dahlkamp, 2010a). Known volcanogenic uranium deposits within the United States are located in Idaho, Nevada, Oregon, and Utah. These deposits produced an estimated total of $800 \mathrm{t} \mathrm{U}$ during mining from the 1950s through the 1970s and have known resources of 30,000 t U (IAEA, 2009). The most recent estimate of speculative resources proposed an endowment of 200,000 t U (Department of Energy, 1980).

\section{Geochemical and Geologic Setting}

Formation of volcanogenic uranium deposits is dependent on extraction of uranium from felsic rocks, transport by hydrothermal solutions, and deposition induced by chemical or physical changes. Uranium concentrations in volcanic rocks increase with differentiation to more felsic compositions. Midocean ridge basalts typically contain 0.2 parts per million (ppm) U (Kelemen and others, 2004), whereas the median content of $U$ in rhyolite in the United States is 5 ppm (Cenozoic rhyolites, $n=1,400$; U.S. Geological Survey, 2011). Felsic volcanic rocks proximal to uranium deposits typically contain uranium concentrations in excess of $10 \mathrm{ppm}$. Enriched uranium contents are characteristic of rocks with aluminous and alkaline affinities (Cuney and Kyser, 2009). This favorability is partly attributed to the low degree to which silica is polymerized in aluminous and alkaline melts. The depolymerization favors retention of uranium and other high-field strength elements in the magma, rather than 
sequestering these elements in early formed refractory phases such as monazite or zircon. High fluorine contents that are typical of uranium-enriched volcanic rocks, similarly limits linking of silica in magmas, which favors the retention of uranium in the melt.

Volcanogenic uranium deposits formed in diverse tectonic settings including: rifts (Osamu Utsumi, Brazil; Lapido Loureiro and others, 1988), hot spots (McDermitt caldera, Nevada; Castor and others, 1996), back arcs (Macusani, Peru; Cheilletz and others, 1992), and subduction zones where the stress field has shifted to be extensional (Marysvale, Utah; Cunningham and others, 1998). The age of rocks hosting these deposits ranges from Proterozoic through the Tertiary; no change in deposit characteristics is apparent with age. Although the origin of felsic magmas in all favorable settings is complex and controversial, enhanced heat flow because of thinning of the crust and rise of mafic magmas likely induce partial melting of relatively uranium-rich upper crustal rocks to create melt compositions that favor enrichment of uranium and other incompatible elements (estimated average $\mathrm{U}$ content of upper continental crustal rocks is $2.8 \mathrm{ppm} \mathrm{U}$; Rudnick and Gao, 2004).

Vein, stockwork, breccia-hosted, and stratabound deposits proximal to volcanic centers have generally similar grades, ore mineralogy, and share common clay mineral alteration assemblages. Vein and stockwork deposits fill fractures and faults that cut volcanic, subvolcanic, and basement rocks. They extend for tens to several hundreds of meters along strike and tens to hundreds of meters in dip. Subvolcanic eruption breccias form pipes that host uranium deposits tens of meters in diameter; the dimensions of these breccias typically decrease with depth. Eruption breccia, flow breccia, and volcaniclastic rock host deposits that are conformable to the bounds of these units, although the feeder for ore-forming fluids is commonly a fracture. These stratabound deposits can extend for hundreds of meters laterally and range from less than one to tens of meters in thickness. Stratiform deposits hosted by lacustrine sediments deposited within a caldera share characteristics of more distal sedimentary-type uranium deposits in which air-fall volcanic ash has a prominent role, but are included in this model because of the inferred role of magmatic heat in fluid circulation. These intracaldera lacustrine deposits can extend laterally for several hundreds of meters and be meters to tens of meters thick. Generally these deposits are of lower grade than other types of volcanogenic deposits.

\section{Ore Mineralogy and Alteration}

Primary ore phases in volcanogenic uranium deposits are typically a mixture of uraninite, pitchblende, and coffinite, with brannerite and uranothorite common in deposits formed in more alkaline rocks. Significant contents of fluorite and molybdenite (jordesite) are common in most volcanogenic uranium deposits; in some deposits they are sufficiently abundant to be recovered as byproduct commodities. Deposits in peralkaline rocks have associated enrichments of rare-earth elements, thorium, and zirconium. A few Hercynian deposits in Europe and Asia are polymetallic as a result of a complex, multistaged hydrothermal history and are noted for their enrichments of copper, lead, silver, and zinc (Dahlkamp, 2010a).

Pre-ore alteration at many deposits includes alkali metasomatism that is followed by varying amounts of quartz, sericite, pyrite, and carbonate mineral veining. Minerals produced during wall-rock alteration include: albite, potassium feldspar, smectite, illite (sericite), kaolinite, dickite, chlorite, calcite, hematite, and pyrite. Growth of uranium minerals is commonly associated with argillic alteration and fluorite. Post-ore fluids redistribute uranium, and produce late-stage carbonate minerals, sulfates, and additional argillic alteration. Alteration of wall rock along vein margins is limited to a few meters, whereas the alteration of the eruption breccias and volcaniclastic deposits is more complete likely reflecting the greater permeability of these host rocks. Paragenesis of the ore and gangue phases is 
difficult to resolve, and is considered as evidence for multiple fluids with distinct compositions during the history of the uranium mineralizing system.

\section{Mineralizing Conditions}

Evidence for the composition of fluids responsible for volcanogenic uranium mineralization is based on stable isotopic and fluid inclusion studies of gangue minerals. Results of these analyses support the mixing of meteoric and magmatic water during formation of most deposits. Volatiles, notably fluorine, chlorine, and $\mathrm{CO}_{2}$ are considered to have a magmatic origin. Fluid inclusion studies indicate mineralization temperatures between 150 and $300{ }^{\circ} \mathrm{C}$ and fluid compositions with low to moderate salinities (less than 8 wt.\% KCl eq.) (Dahlkamp, 2010a; 2010b). Smaller, low-temperature deposits (less than $100^{\circ} \mathrm{C}$ ) within volcaniclastic rocks are speculated to have formed by the release of uranium during weathering of the volcanic rocks.

Uranium is generally thought to be transported in the ore-forming fluids as the more soluble U(VI) species (uranyl ion), rather than as U(IV), which is the oxidation state in the primary ore minerals. Accordingly, formation of ore is attributed to chemical reduction. Proposed reductants include reduced sulfur species $\left(\mathrm{H}_{2} \mathrm{~S}\right.$, thiosulfate, and other polythionates) (Nash, 2010) and ferrous iron in wall-rock minerals. Carbonaceous matter in lacustrine sediments and some volcaniclastic rocks likely contributed to reduced sulfur forms in those rocks by local low-temperature bacterial sulfate reduction. Reduction of uranium by dissolved sulfur species would require mixing of oxidized and reduced fluids, which is problematic in some vein systems. Reaction with ferrous iron in the wall rock is offered to account for the frequent association of hematite with reduced uranium oxides in some deposits. Although silicic volcanic rocks have relatively low iron content, only 0.5 weight percent $\mathrm{Fe}^{2+}$ is necessary to reduce sufficient uranium to produce a volumetrically equivalent rock containing $1 \mathrm{wt} . \%$ U. The median iron content of Cenozoic rhyolites in the United States is 1.7 wt.\% (U.S. Geological Survey, 2011). In some systems boiling of the ore-forming fluid, whereby soluble uranium complexes are destabilized by loss of $\mathrm{CO}_{2}$ and fluoride, may have been more significant than uranium reduction in ore formation (Cunningham and others, 1998).

\section{Weathering Effects}

Weathering of volcanogenic uranium deposits typically forms supergene deposits of potential ore grade. Minerals in weathered deposits include silicates (uranophane and beta-uranotile), phosphates (autunite), hydroxides (curite), and some vanadates (carnotite). Gangue minerals associated with the supergene accumulations are secondary kaolinite and smectite with ferric oxyhydroxides.

\section{Exploration}

Areas favorable for volcanogenic uranium deposits typically have uraniferous basement rocks. Partial melting and fluid interaction with the basement are thought to contribute to the uranium content of the felsic volcanic rocks that host the deposits. Late Mesozoic deposits in Russia and China are known to overlie felsic Proterozoic basement rocks with uranium contents in excess of $10 \mathrm{ppm}$. The area of the giant Streltsovskoye district experienced two episodes of silicic magmatism marked by uranium enrichment, prior to the late Mesozoic volcanism that is linked to ore formation (Golubev and others, 2010). The identification of regions with progressive concentration of uranium by successive magmatic episodes may aid in identification of favorable terrain.

Detection of volcanogenic uranium deposits relies on geophysical and geochemical surveys, as well as subsequent target drilling. Radiometric measurements are the most effective geophysical 
method for detection of potential areas for volcanogenic uranium deposits. This approach would detect uranium enrichment in deposits, as well as favorable rocks to host these deposits. Elevated concentrations of uranium, fluoride, and molybdenum in rock, water, and stream sediments are favorable indicators. At Streltsovskoye drill testing of fluorite veins that have no apparent uranium enrichment at the surface was the best technique to locate ore bodies. Volcanogenic uranium deposits that have no surface expression are suited for exploration methods applied to other uranium deposits, including geochemical sampling of soil gas (radon) and groundwater for uranium and indicator elements.

\section{Environmental Concerns}

Environmental hazards associated with volcanogenic uranium deposits are attributed to the release of uranium, radioactive daughter products, and associated elements. Exposure to uranium in dusts and water is regulated because of its chemical toxicity. Oxidation of the primary uranium minerals during weathering or exposure during mining operations produces the soluble uranyl ion. This form of uranium is readily transported in surface and groundwater, although reactions along the transport path of solutions with high contents of uranium near a uranium deposit may cause low solubility uranium silicates, phosphates, hydroxides, or vanadates to form. Alternatively, even small concentrations of dissolved uranyl ion can accumulate to economic concentration in reducing environments such as wetlands. The U.S. Environmental Protection Agency has set the drinking-water standard for uranium to be $30 \mu \mathrm{g} / \mathrm{L}$, which can be greatly exceeded in uranium mines (Caine and others, 2011). The products of radioactive decay, notably radium and radon, are considered radiological hazards and are also regulated by the U.S. Environmental Protection Agency. Radium forms a soluble ion that is readily leached from uranium ore. Dissolved sulfate can limit radium transport by forming low-solubility minerals such as barite which will incorporate radium. Radon is a short-lived radioactive gas that is a likely hazard proximal to the uranium ore bodies and waste piles. In contrast to many basemetal deposits, uranium deposits have generally low contents of sulfide minerals, and typically have gangue mineral and wall-rock composition with moderate to high acid-buffering capacities. The circum-neutral $\mathrm{pH}$ of drainage from volcanogenic uranium deposits limits the mobility of many elements associated with these deposits. Nonetheless, concentrations of dissolved fluoride and molybdenum may exceed regulatory standards in areas of undeveloped and mined volcanogenic uranium deposits.

\section{References}

Caine, J.S., Johnson, R.H., and Wild, E.C., 2011, Review and interpretation of previous work and new data on the hydrogeology of the Schwartzwalder uranium mine and vicinity, Jefferson County, Colorado: U.S. Geological Survey Open-File Report 2011-1092, 55 p.

Castor, S.B., Henry, C.D., and Shevenell, L.A., 1996, Volcanic rock-hosted uranium deposits in northwestern Nevada and southeastern Oregon-Possible sites for studies of natural analogues for the potential high-level nuclear waste repository at Yucca Mountain, Nevada: Nevada Bureau of Mines and Geology Open-File Report 96-3, p. 12-26.

Cheilletz, Alain, Clark, A.H., Farrar, Edward, Pauca, G.A., Pichavant, Michel, and Sandeman, H.A., 1992, Volcano-stratigraphy and ${ }^{40} \mathrm{~A} /{ }^{39} \mathrm{Ar}$ geochronology of the Macusani ignimbrite field: Monitor of the Miocene geodynamic evolution of the Andes of southeast Peru: Tectonophysics, v. 205, p. 307327. 
Cuney, Michel, and Kyser, Kurt, 2009, Recent and not-so-recent developments in uranium deposits and implications for exploration: Mineralogical Association of Canada, Short Course Series v. 39, 257 p. Cunningham, C.G., Rasmussen, J.D., Steven, T.A., Rye, R.O., Rowley, P.D., Romberger, S.B., and Selverstone, J., 1998, Hydrothermal uranium deposits containing molybdenum and fluorite in the Marysvale volcanic field, west-central Utah: Mineralium Deposita, v. 33, p. 477-494.

Dahlkamp, F.J., 2010a, Uranium deposits of the world volume 1, Asia: Berlin, Springer-Verlag, 945 p.

Dahlkamp, F.J., 2010b, Uranium deposits of the world, volume 2, USA and Latin America: Berlin, Springer-Verlag, $423 \mathrm{p}$.

Department of Energy, 1980, An assessment report on uranium in the United States of America: United States Department of Energy Report, GJO-111(80), 157 p.

Golubev, V.N., Chernyshev, I.V., Kotov, A.B., Sal'nikova, E.B., Golzman, Yu.V., Bairova, E.D., and Yakovleva, S.Z., 2010, The Strel'tsovka uranium district: Isotopic geochronological (U-Pb, Rb-Sr, $\mathrm{Sm}-\mathrm{Nd}$ ) characterization of granitoids and their place in the formation history of uranium deposits: Geology of Ore Deposits, v.52, p. 496-513.

Goodell, P.J., 1985, Classification and model of uranium deposits in volcanic environments in International Atomic Energy Agency, Uranium deposits in volcanic rocks: International Atomic Energy Agency Panel Proceedings of a Technical Committee Meeting, El Paso Texas April 2-5, 1984, p. 1-17.

International Atomic Energy Agency, 2009, World distribution of uranium deposits (UDEPO) with uranium deposit classification: Vienna, Austria, International Atomic Energy Agency, IAEATECDOC-1629, 117 p., Accessed June 2011 at http://www-pub.iaea.org/MTCD/publications/PDF/TE_1629_web.pdf.

Kelemen, P.B., Hanghoj, K., and Greene, A.R., 2004, One view of the geochemistry of subduction related magmatic arcs, with an emphasis on primitive andesite and the lower crust, in Holland, H.D., and Turekian, K.K., eds., Treatise on Geochemistry: Amsterdam, Elsevier, v. 3, p. 593-659.

Lapido Loureiro, F.E.de V., and Dos Santos, R.C., 1988, The intra-intrusive uranium deposits of Pocos de Caldas, Brazil: Ore Geology Reviews, v. 3, p. 227-240.

Nash, J.T., 2010, Volcanogenic uranium deposits: geology, geochemical processes, and criteria for resource assessment: U.S. Geological Survey Open-File Report 2010-1001, 110 p.

Rudnick, R.L. and Gao, S., 2004, Composition of the continental crust, in Holland, H.D., and Turekian, K.K., eds., Treatise on Geochemistry: Amsterdam, Elsevier, v. 3, p. 1-64.

U.S. Geological Survey, 2011, National geochemical database: Rock: accessed 8/25/2011 at http://tin.er.usgs.gov/ngdb/rock/.

Publishing support provided by:

Denver Publishing Service Center

For more information concerning this publication, contact:

Center Director, USGS Central Mineral and Environmental Resources Science Center

Box 25046, Mail Stop 973

Denver, CO 80225

(303) 236-1562

Or visit the Central Mineral and Environmental Resources Science Center Web site at: http://minerals.cr.usgs.gov/ 